James Costa

\title{
New speakers, new language: on being a legitimate speaker of a minority language in Provence
}

\begin{abstract}
This article looks at the "new speaker" concept and the questions it raises in terms of legitimacy from the point of view of several types of social actors, namely language advocates, academics and school pupils (that is to say, "new speakers" themselves). The aim of this article is to show that this notion is not a purely descriptive one, but also carries a strong prescriptive loading - which in turns requires that minority language learners negotiate their participation in linguistic markets. Based on fieldwork in Provence, I look at how "new speakers" are often construed as speakers of "new languages", "standard" or "artificial" languages that tend to index youth, urbanity, modernity and middle class membership - all qualities which may be seen as undesirable in parts of minority language movements. I then turn to pupils of an Occitan bilingual primary school in Provence and analyse how they reframe the new speaker debate in order for themselves to fit in the broader picture of Occitan speakers. All the viewpoints I analyse tend to emphasise the weight that the traditional, monolingual speaker still holds among speakers of minority languages in southern France.
\end{abstract}

Keywords: linguistic market, legitimacy, new speakers, immersion schools

DOI 10.1515/ijsl-2014-0035

\section{Introduction: new speakers of minority languages and legitimacy on linguistic markets}

Several scientific conversations tend to classify speakers in terms of linguistic competence. Among them, the most well known is probably the one in the field of endangered languages (e.g. Grinevald and Bert 2011: 49-52). Categorisations are then used to rate and classify the type of structural data that researchers

James Costa: University of Oslo, Norway. E-mail: james.costa@iln.uio.no

(c))BY-NC-ND (c) 2015 Costa, published by de Gruyter. This work is licensed under the Creative Commons Attribution-NonCommercial-NoDerivs 3.0 License. 
may elicit from informants on the ground. In that particular conversation, new speakers (sometimes called "neo-speakers") fare alongside other categories such as the well-known semi-speakers, fluent speakers, ghost speakers etc. In this article however, I use the term as used in discussions on the future of minority languages: new speakers are construed as the desired outcome of language and education policies that aim at sustaining their usage. According to this particular view, new speakers must replace old ones as they fall silent.

\section{1 “New speaker” as a prescriptive label?}

In this article, I wish to argue that the "new speaker" label is never a purely descriptive one, and often serves to generate norms as to what a legitimate speaker of legitimate language is or should be. This label is slightly confusing perhaps, as it is being used by language advocates in several contexts (e.g. Brittany, the Basque Country) as well as by academics - with different purposes in mind. I am therefore interested in the following questions: what is the "new speaker" notion used for, and by whom? And how is legitimacy negotiated by those who fall under that very label, i.e. second language learners? In order to achieve this, I will first look at how language advocates and academics construe new speakers; I will then turn to the discourse of pupils of a bilingual school in Provence in order to analyse how they construct their own legitimacy as individuals, as language users and as speakers of a minority language.

The "new speaker" category serves to categorise people in terms not only of language proficiency but also as members of different groups occupying various social positions due to this competence. In this respect, the idea of being a new speaker comes with a loading of political and moral issues about what it means to use a legitimate variety of any given language, and about what it means to be a genuine member of a (linguistic) group. I concentrate here on the Provençal context in southern France, basing myself on fieldwork I conducted between 2007 and 2010 in northern Provence where I focused mostly on a parent-run school, part of the Calandreta network of private Occitan immersion schools. (There is a recent but ongoing debate in Provence as to whether Provençal is a distinct language or a dialect of a larger language, Occitan. In this article however, both terms will be used interchangeably.)

\subsection{Linguistic markets and language legitimacy}

In this article, I understand language as a product that circulates on a number of markets. This product is subsequently the subject of various types of evaluation. 
Bourdieu defines linguistic markets as loci where participants exchange linguistic products, i.e. stylistically marked discourses (Bourdieu 1977, 1991: 38-39). A linguistic market is a site where discourses and features of speech are evaluated and receive a price. Beyond discourses, individuals are constantly evaluated on the linguistic markets in which they take part through the evaluation of their linguistic products. The price of minority languages (or the symbolic rewards for using such languages) is usually very low on unified linguistic markets, but they may receive a higher price on niche markets where they can index a sense of community, solidarity or authenticity. In this case, Occitan is profitably conceived of as a post-vernacular language (Shandler 2006: 19-30), one for which the communicative functions of the language are no longer the primary reasons for its usage. The very fact that they are used at all is often more important than the meaning of the words that are uttered.

Legitimacy is the ability to utter the right linguistic forms at the right linguistic moments in the right situations, and to comply with the type of discourse that society expects one to produce. Legitimate language ...

\footnotetext{
... is uttered by a legitimate speaker, i.e. by the appropriate person, as opposed to the impostor ... it is uttered in a legitimate situation, i.e. on the appropriate market ... and addressed to legitimate receivers; it is formulated in the legitimate phonological and syntactic forms ... except when transgressing these norms is part of the legitimate definition of the legitimate producer. (Bourdieu 1977: 650)
}

Legitimate language is not a given. It is constantly negociated among users, and what constitutes legitimate language may vary according to the setting in which it is used. I argue that legitimacy is destabilised by the death of traditional speakers, and its definition constitutes a central question in contemporary minority language groups, not only in terms of who can claim language ownership, but also in terms of who counts as a legitimate member of the group, or not.

\section{New speakers and legitimacy on the Provençal linguistic market}

Discussing the status of new speakers of Occitan has been an ongoing topic among both language advocates and academics for several years. I describe briefly the nature of those discussions below, showing in particular how issues of legitimate language (and therefore of legitimate speakers) are central. 


\subsection{New speakers according to language advocates}

In the south of France, some language advocates who have consciously learnt the minority language do tend to increasingly call themselves neo-speakers (néolocuteurs), to emphasise the fact that Occitan is not their first language. Many, however, use the term in a derogatory way. Consider for example this contribution to a discussion thread on the Projetbabel.org forum, a French forum designed for language lovers. The thread itself is entitled: Eth gascoûn: ua auta lenga que l'ouccitân? 'Gascon: a language other than Occitan?':

La novlang que parlent les néo-locuteurs est un dialecte pour le coup occitan de vague inspiration gasconne, qui si on l'analyse proprement, n'est que du français traduit mot à mot. Et encore, je parle d'une génération qui a eu la chance d'avoir des enseignants parfois fins locuteurs. La génération nouvelle des Calandretas parle une langue complètement loufoque, une sorte de titi parisien super-nasal avec des -o à la fin (qu’ils prononcent -e en fait ...). ${ }^{1}$

[The newspeak used by new speakers is clearly an Occitan dialect with a vague Gascon inspiration, which, if properly analysed, is but word for word French. And I'm speaking of a generation that was lucky enough to be taught by teachers who were fine speakers. The new Calandreta generation speaks a completely barmy language, a sort of super-nasal Parisian slang with -o at the end [of words] (which in fact they pronounce -e ...). $]^{2}$

The author establishes a seemingly obvious connection between the type of Gascon used by neo-speakers and Orwellian newspeak, suggesting both the artificial nature of the language as well as its use for manipulative purposes. This type of (very habitual) comment underlines, however, the current struggle that pervades the Occitan language movement as to which linguistic forms carry authority and, ultimately, who is legitimate to impose new forms of authenticity linked with language, now that traditional speakers are disappearing.

\subsection{New speakers for academics: a descriptive category?}

The term néo-locuteur is also used in academic (mostly sociolinguistic) conversations, where it may also acquire both apparently neutral and derogatory meanings. As an apparently neutral category, consider the following excerpt from historian Philippe Martel's (2001) article on language policy in southern France:

1 Available on the Projetbabel.org website: http://projetbabel.org/forum/viewtopic.php?p= 165312, accessed 10 September 2012.

2 All translations are mine. 


\begin{abstract}
Mais contradictoirement, les langues de France fonctionnent - et on l'a vu depuis plusieurs décennies déjà - comme langues choisies par des néo-locuteurs qui sont le plus souvent de purs produits de l'école française ... . (Martel 2006: 383)

[But contradictorily, the languages of France now function - and have been for several decades now - as languages chosen by neo-speakers who are most often pure products of the French school system ... .]
\end{abstract}

While Martel intends the category to be a descriptive one, he does not specify what it describes, other than that it relates to individuals who have consciously made the choice to learn Occitan. He says nothing of the status of such individuals in the south of France, of their position on the Occitan linguistic market, or of the linguistic varieties they speak.

Another academic who uses the term while referring to Provence is the sociolinguist Philippe Blanchet, a staunch advocate of Provençal as a distinct language (rather than as a dialect of Occitan). He correlates new speakers with neoProvençal, with distinct signs of lack of legitimacy, and associates their speech with indexes of youth, urban and middle-class lifestyles - which according to him are far removed from what authentic Provençal is or ought to be. Consider for instance the following two excerpts from his writings, the first from a scientific study, the second from a Provençal teach-yourself manual:

(1) Le "néo-provençal » est un provençal fortement francisé, surtout dans ses structures syntaxiques et phraséologiques, réguliers chez les jeunes militants urbains. (Blanchet 2002: 33)

["Neo-Provençal" is a highly frenchified Provençal, especially in its syntax and phraseology, regular among young urban activists.]

(2) On notera surtout une différence entre le provençal des conversations spontanées des locuteurs "naturels » et celui des activistes, enseignants, écrivains, présentateurs à la télévision etc. qui l'ont parfois appris volontairement et plus ou moins artificiellement. Les locuteurs "naturels» utilisent davantage de mots empruntés au français mais ont une syntaxe et une stylistique typiquement provençales. Les locuteurs volontaires ont un vocabulaire "épuré » (parfois au point d'utiliser des formes curieuses) mais une syntaxe et une stylistique influencées par le français normatif (parfois calquées mot à mot). Les seconds se recrutent heureusement parfois parmi les premiers! (Blanchet 1999: 22) [One should pay specific attention to the "natural" speakers' Provençal of spontaneous conversations and that of activists, teachers, writers, television presenters etc. who have sometimes learnt it on a voluntary and more or less artificial basis. "Natural" speakers use more words borrowed from French but their syntax and stylistics are typically Provençal. Wilful speakers have an 
"expurgated" vocabulary (sometimes to the point that they use curious forms) but their syntax and stylistics are influenced by normative French (sometimes on a word for word basis). Fortunately, the latter [i.e. Teachers, presenters etc.] are sometimes recruited among the former!]

This discourse draws on several layers of meaning in Provence, in particular on the distinction between proponents of Provençal as a dialect of Occitan, and those in favour of Provençal as an independent language. While the former are usually construed as younger and more often as leading urban lifestyles, ${ }^{3}$ the latter are believed to come from more rural backgrounds, and to have more contact with native speakers. "Wilful speakers" are here supposed to be recruited among the former. Two types of authority are thus at play: one derived from the social symbolic benefits associated with urban culture in modernity, and the other from traditional patterns of language use and from the prestige of the native speaker.

What emerges is the construction of an apparently clear-cut dichotomy between new and traditional speakers, indexed through the type of speech that users display, as shown in Table 1 (see also O'Rourke and Ramallo 2011: 150-151).

Table 1: The discursive dichotomy between ordinary and new speakers

\begin{tabular}{ll}
\hline Ordinary speakers & New speakers \\
\hline Rural & Urban \\
Old & Young \\
Working class & Middle class \\
Continuity, tradition, authenticity & Rupture, artificiality \\
\hline
\end{tabular}

\subsection{New speakers as discursive category}

“New speakers” can be interpreted as a discursive category in its own right, based not only on the recent acquisition of a language, but on the very type of language

3 While this features prominently in discourse, the reality is obviously far more complex. I have shown elsewhere (Costa 2011) that this struggle carries clear social class undertones and can be read as the transposition by mostly working class movements of a larger fight against "globalisation", an elusive and disembodied reality, into a more concrete battle against real people, the "Occitanists", whose alleged middle class membership turns them de facto into proponents of globalisation. 
that those ascribed to it use as well as the indexical order it conjures. In that respect, "new speakers" are a category that serves the interests of some social actors, those holding authority, and on the other hand condemns others to either aligning with what authoritative language ought to be, or to establishing parallel linguistic markets. The existence of "new speakers" as a category thus makes possible the fractal replication of diglossia at the level of the minority language.

The language of new speakers of minority languages is thus liable to being termed, for instance, néo-breton (Le Berre and Le Dû 1999), néo-provençal (Blanchet 2002) etc. and often refers to standardised or literary varieties (Hincks 2000), i.e. varieties often thought of as invented or artificial. Writing on Breton, Mari Jones thus quotes language advocates referring to the language of new speakers as “a form of Celtic Esperanto" (Jones 1995: 437). This in turn echoes the term "newspeak" that was used by a Gascon activist above. This new language is often understood as artificial, literary, normative, reconstituted or idiosyncratic (Lafont 1997, 1984), urban, young, and displaying the wrong aspects of contact with the dominant language. Syntactic and prosodic features influenced by the dominant language are thus largely condemned. On the contrary, the lexical borrowings of traditional speakers embedded in more traditional syntax are seen as authentic and as indexing the true native speaker.

What this points to is the existence of idealised varieties of minority languages, which the French sociologist of language Pierre Achard (1982) called the myth of the lost language. In turn this hints at the existence of legitimacy in language use as lying elsewhere, in an indeterminate locus, among indeterminate others. The advantage of this particular locus being of course that its definition is variable, and can be adapted by different actors to suit various needs in various occasions. Of key importance here is the potential fuzzy and uncertain type of differentiation it generates, which can for instance be used by teachers to justify the existence of evening classes, by native speakers to exclude younger people from conversations etc.

The question one may legitimately ask, however, is whose interests these varieties serve. That is to say, if they are of little value on traditional linguistic markets, on which markets are they valorised and exchangeable, and by whom? Far from being a neutral descriptive term, the notion of "new speakers" is therefore loaded with a wealth of political, social and moral issues. It is connected with the type of language that should be taught to children in schools, and the types of social and indexical links social actors seek to foster - e.g. repairing a broken connection with older generations (Le Berre and Le Dû 1999) or battling against an ongoing diglossic complexus (Lafont 1997). 


\section{Legitimacy among bilingual school pupils in Provence: between old and new language}

In this section, I turn to ethnographic fieldwork among pupils of an Occitan immersion primary school in Provence to explore precisely how issues of legitimacy are problematised by the children involved in such programmes. In so-called language revitalisation movements, schools are thought to be one of the primary sites for the generation of new speakers, while simultaneously they remain central sites for the definition and reproduction of standard and legitimate language. In this case, school pupils both stand for the use of an academic norm, a second language, and youth. Language advocates construe them as the future of the language, but concomitantly they tend to judge their language as not as legitimate as that of traditional speakers, in particular because of their accent, which tends to be marked by contact with French. Their own views on language are thus central to the analysis of new forms of linguistic legitimacy.

I first look at how legitimacy in the use of Occitan is constructed among the children within the school, before examining how pupils handle such issues when faced with the language of traditional speakers.

\subsection{Fieldwork in an Occitan immersion school}

I began fieldwork in 2007 in a small town in Provence, mostly in and around a private Occitan immersion primary school in Provence. The pupils clearly did not regard the minority language as a burden, and even saw it as a source of pride. It was, in their own words, their language. Yet for a number of reasons it was far from being used as the primary language of everyday interactions with peers, and remained the language of the sole classroom. The way the children used language, and what they used it for greatly differed from what took place in society at large (outside the school). In the town where the school is located, there are indeed no or few traditional speakers left, although two associations run events in or about the language.

The school itself is part of the Calandreta network of immersive Occitan schools, which in 2012 involved almost 3,000 pupils across the south of France. A combination of innovative pedagogical approaches based on the pioneering work of Célestin Freinet (which emphasised the agency of pupils in their own learning - see Legrand [1993]) and a focus on bilingualism makes them attractive to parents of all origins. My interviews showed that few, if any, of the pupils used Occitan at home on a regular basis, and parents' motivations for choosing this 
particular school ranged from language activism to an interest in bilingualism in general or in alternative pedagogy.

All classes take place in Occitan, and from the age of seven children are also taught to read and write in French (taught as a subject on a forty-five minute daily basis). French is not normally permitted inside the classroom, but may be used during recess.

\subsection{The classroom as a linguistic market}

The official Calandreta discourse emphasises bilingualism rather than competence in one language or another. The children are thus construed as "bilinguals", a fundamental term in the construction of the school network's identity. Paradoxically however, bilingualism is assumed to be a reality in the everyday experience of children, but is not valued as such in the school - Occitan and French are, for example, taught in different rooms or, as it happened, in different buildings. The school linguistic market is therefore strictly regimented: Occitan should be used at all times in the classroom, and lapses into French are discussed and analysed by the group with the teacher, and sanctioned (with fines - see below). Occitan can, however, be used in the French language class. Occitan is encouraged in the playground, although no particular measures are enforced to ensure that the language is used.

The school thus functions as a closed linguistic market with its own rules and its own hierarchies. The market itself is materialised by a number of practices that are connected to the type of pedagogy used in the school. Pupils can volunteer for jobs (e.g. completing a daily meteorological chart) and get paid for them in a currency that is established through common agreement at the beginning of the year. Antisocial behaviour (as defined by the whole group at the beginning of the year) and the use of French in the classroom can result in fines. Every Friday, a market is held where pupils can bring objects from home (posters, badges, drawings, toys etc.) and sell them for either units of the class currency or exchange them for other goods. Prices are set by pupils individually, and can result in negotiations. In this context, language itself can be seen as an asset that may command authority and status amongst pupils. Occitan is maintained throughout some negotiations while others will take place in French, despite the explicit rule that French should not be used in the classroom. Those who sustain interactions through Occitan are best portrayed as norm keepers (both in school and linguistic terms), and are likely to be better negotiators or to command more authority.

Another instance of the workings of the class linguistic market can be observed during the Qué de nòu? 'What's up?' moment every Monday morning, 
when children are expected to tell fellow pupils something about their weekend. This moment is chaired by one of the pupils, who manages the floor and ensures that everyone gets to speak. Again, speech is closely monitored by some of the pupils who act as norm-keepers. This is manifested both through their own discourse, which tends to be more fluid and to contain richer vocabulary, and through epistemic stance taking (correcting pronunciation and vocabulary, providing proper morphological forms and metadiscursive comments on others' mistakes such as Mai lo fas exprès, es “autre” 'but are you doing it on purpose, it's "autre"'; see also below, Section 3.3). Likewise, a felicitous turn of phrase on the part of younger pupils may be met with approval and praise. Language is thus one of the focal points of collective concerns, and the linguistic productions of students are constantly monitored. Command of Occitan is therefore central in the establishment of hierarchies of legitimacy. In this respect, language is admittedly an essential marketable item, but more than language itself, it is the capacity to produce metalinguistic comments that function as markers of authority. Those who make such comments may indeed well reproduce the very mistakes they keenly identify in the speech of others.

\subsection{Language in the classroom and beyond: a tale of three pupils}

I now turn to a closer analysis of a one hour-long sociolinguistic interview that I conducted in April 2008 with three pupils from the class I observed: Léa (then aged 10), Carla (11) and Safia (12), in order to understand how the children perceived and analysed language use in their school environment. Two elements are immediately apparent: hierarchies based on language use are replicated within the classroom, and pupils must adapt and reflect upon their use of language when confronted to the world outside school.

\subsubsection{Establishing hierarchies through language}

Not only did the pupils interact with me during the interviews, they also interacted with each other, displaying the very mechanisms that serve to establish authority and legitimacy locally, as well as making clear how Occitan was relevant to their everyday lives and socialisation processes as children, as pre-adolescents, as girls, and as participants in activities such as football or music associations. In the interview I discuss here all three girls insisted that the interview be conducted in Occitan. 
In order to analyse how the pupils constructed their positions of legitimate users (or not) of Occitan, I draw on Jaffe's (2009) distinction between epistemic and affective stances to analyse the various positions that the girls display in interaction. Epistemic stances refer to "claims to know" and serve "to establish the relative authority of participants, and to situate the sources of that authority in a wider sociocultural field" (Jaffe 2009: 7). Affective stances "represent emotional states of the speaker" and have two main functions: they relate to evaluation, presentation and positioning of the self; they can also "index shared, culturally specific structures of feeling and norms ... and can thus be mobilized in the drawing of social boundaries that is central to the work of social differentiation and categorization" (Jaffe 2009: 7).

Throughout the interview, the pupils alternate between epistemic and affective stances. Léa, Carla and Safia use both types as ways to establish (and further) their own position with respect to one another, to display legitimacy in the eyes of the interviewer (through the insertion of short narratives explaining that the girls often lapse into Occitan on occasions when it is not expected, e.g. at home with their parents). In the context of the interview, linguistic resources are managed in a very normative way: infelicitous utterances (e.g. marked by contact with French, grammatical errors) are immediately corrected by Léa and Carla, who establish themselves as authorities with regard to Safia. Correct language is however not the only element that establishes authority. In the following extract, Carla interrupts the flow of the conversation to ask Léa why she speaks such good Occitan, since she arrived in the school after her and Safia:

1 Carla una question mai just per ca es per Léa / es ti a question but just for ca its for léa / did you avans / avans que sias venguda aqui an aquesta escòla eh before / before you came here in this school well ben coneisses lo provençau? coneissiáu / coneissiás did you know provençal? knew / know

4 Léa coneissaviás lo provençau [proposes to correct Carla] knew provençal

5 Int. coneissiás know

6 Carla òc coneissiás lo provençau? yes did you know Provençal?

7 Léa euh /// bòna question [laughs] alòra es parier que mei well /// good question [laughs] so it's like my copinas a la dança ai vist de paneus e tot / mai euh friends at the dance I had seen signs and all / but 
9 Carla coneissiás pas you didn't know it

10 Léa mai aviau jamai entendut [parlAR I'd never heard it [spoken

11 Carla Lpas un mòt euh [not a word

12 Léa ja aviáu jamai entendut parlar d'una escòla / calandreta to begin with I'd never heard of a school / calandreta

13 e siáu fòrça d'alhors contenta de la de lo saupre / ara and I'm really happy to know about it / now

14 e d'i èstre and to be here

15 Carla en tot cas a fòrça lèu aprés lo provençau anyway you learnt provençal really quickly

16 Léa pense COma / ditz Danieu es perdequé es coma èstre fòrt I think like / Daniel ${ }^{4}$ says it's because it's like being en provençau ajuda en francés / èstre fòrt en francés good at provençal helps for french / to be good at ajuda au provençau / va dins lei dos sens / pense french helps for provençal / it goes both ways / I think

In the extract above, Carla derives her own legitimacy from the fact that she has been in the Calandreta system all her life. Her hesitations at first on the past tense form of the verb conoisser 'to know' (lines 2-3) do not alter her own status with respect to the other two girls. In contrast to Carla, who derives her own position on the linguistic market from interplay between epistemic and affective stances (she regularly proclaims her loyalty to Occitan as a beautiful language, and as a language related to Italian, a language spoken in her family), Léa draws her legitimacy from mostly epistemic stances. In the extract above, Léa infers her ability to learn Occitan quickly from of her (good) knowledge of French, not from language loyalty - an argument she borrows from the ultimate source of authority in the class: the teacher.

The floor is shared between Carla and Léa, who compete internally for a dominant position within the classroom linguistic market on different grounds; Safia on the other hand repeatedly displays marks of linguistic insecurity. The issues that are questioned internally reflect those that are questioned outside the classroom: the capacity to produce felicitous utterances on the linguistic market as

4 Daniel is the teacher. 
well as seniority in group membership. "Newspeakerhood" is imported, reproduced and contested inside the group, and the example above shows how seniority (or lack thereof) in a group are but one element among others in the evaluation of utterances (and of individuals) on a linguistic market. Legitimacy occurs at the crossing between many elements that involve a combination of epistemic as well as affective stances, of grammatically correct language use as well as of the ability to speak with authority on language. This short analysis shows therefore how seniority is but one element in the construction of legitimate language use inside the restricted group. It is potentially something that should also be analysed in society at large.

\subsubsection{Encountering the native speaker: reframing language into old vs. new Provençal}

Classroom rules have a life of their own however, and the girls' language is evaluated in different ways outside the classroom in a variety of situations that are related to their status as pupils in an Occitan school, as speakers of Occitan, as girls and as children.

All three pupils are fully aware of the price of Provençal on linguistic markets when school is over. Carla thus repeatedly resorts to the notion of "shame" to describe why she does not use Provençal outside school, in particular when playing football in her club, where other participants are predominantly boys. It is, in her own words, difficult enough to be a young girl without adding the mockery that revealing the Provençal component of her linguistic repertoire would entail. Negative social evaluation is therefore connected as much to Provençal itself as to a particular variety of the language - to the language itself rather to what is said or how it is said. However, one may also suggest that the lack of value of Provençal outwith the school is precisely what confers its value within the school. The virtual absence of social evaluation other than that of the teacher allows Provençal to function as a commodity that is easily controlled by a small group of children inside the school. In that respect, confrontation with a more unified linguistic market may question this very legitimacy internally, as in the next extract from the interview.

I presented the pupils with an extract from an interview I had conducted with an eighty-seven year-old woman, Mrs R., living in same town in Provence. I originally sought to observe how they would evaluate her speech. Provençal was her first and only language until the age of ten (roughly the age of the girls at the time of the interview), when she was taught French. In the extract I played, she recounts a dream she had in Provençal some months before. 
At first, Carla asks what is wrong with the woman and the children make fun of her. The situation is thus framed as us (young people) vs. her (old woman), with the usual loading of stereotypes attributed to age - stuttering and memory loss in particular. I then intervene and explain that the woman learnt French at a much later age, and that Provençal was in fact her first language:

1 Carla DETZ ANS / avans parli provençau

[at] TEN YEARS OLD / before I spoke provençal ${ }^{5}$

2 Int. parlava QUE provençau she spoke only provençal

3 Carla la cha::nce how lucky:

4 All la cha:nce how lucky

$5 \quad$ Carla elle est née quand? when was she born?

6 Int. elle a vuechanta vuech ans doncas elle est née en 1921 euh She is eighty eight so she was born in 1921 er what am I

7 qu'est-ce que je vous dit 192122 quelque chose comme ça saying 192122 something like that

8 Carla ouh la la $0: \mathrm{h}$

9 Léa en 1921 In 1921

10 Carla 1921! mai alòra perqué siáu pas nascuda en 1921? 1921 ! But so why wasn't I born in 1921?

This information, which I initially gave in defence of the women I had interviewed, proved more powerful than intended. It revealed an aspect of Provençal history of which the girls were unaware of - that Provençal was once the first language of people in their area. The new element of information provoked a change in footing expressed through code switching to French (1.3), that reframed the interaction as one where authority shifts from the girls to the interviewed woman. I interpret this shift as informed by an ideology that confers natural legitimacy onto the native speaker and monolingualism. Carla finally resumes using

5 What Carla expresses here is stupefaction at the fact that Mrs. R spoke no French before the age of ten. 
Occitan when she seeks to align with the aged woman, by wishing she had been born in 1921 (line 10).

However, this second shift in legitimacy is only partially solved through alignment. In a third movement, after hearing a longer excerpt from the interview with Mrs R., the girls analyse the type of language they have heard with respect to their own, and frame differences as naturally occurring variation:

1 Int. vaquí / doncas aquò es una dòna d'------ / doncas / vos right / so this is a woman from ------ / so / does your sembla different lo provençau que parlatz vosautrei de son provençal seem different provençau an ela? to hers?

4 Carla [ouh la la vò vò vò [oh yes yes yes

[...]

5 Léa [vò mai es de vielh / de vieux vieux vieux provençau aquò [yes but this is old / old old old provençal

6 Carla [vò ieu ai pas tròp comprès çò qu'a ditz [yes I didn't quite understand what she said

7 Int. de que cambia de qu'a fòrça cambiat [entre vòstre accent e what changes what has changed a lot [between your accent and

8 Carla [ben sabe pas euh / ja son [well I don'y know er / her accent / son accent e puei euh /// quelque chose qu'a qu'ai accent / her accent and er /// something I didn't I didn't pas trò:p comprès en fach es lei es lei mòts ai pas tròp tròp quite understand in fact is the is the words I didn't quite tròp comprès / l'accent parlava lèu ja / un pichòt pauc lèu e quite understand / the accent she spoke fast / a little too puei euh / es vielha doncas a pas lo meme provençau que fast and er / she's old so she doesn't have the same provençal nosautrei / mai a due èstre fòrça contenta / d'èstre pendent as us / but she must have been very happy / to be speaking tres tres oras

For three hours

15 Int. quand dises qu'es vielha doncas a pas lo meme provençau que when you say she's old so she doesn't have the same provençal nosautrei perqué dises aquò? as ours why do you say that? 
17 Carla ben perqué es un nov alòra es un novèu provençau çò que well because it's a ne so it's a new provençal what parlam / ela fin i a plusiors provençaus e ela fasia un we speak / she I mean there are several provençals and she provençau different de nosautrei pensi has a different provençal I think

20 Int. vòs dire que avans lo provençau èra different o que? you mean provençal was different before is that it?

21 Carla ben avans lo provençau pensi qu'èra qu'èra presque parier well before provençal I think was almost the same mai / un autre provençau en fach / aquò es un novèu provençau but a different one in fact / this is a new provençal e euh en mila / quauquaren là eh ben èra un autre provençau / and er in nineteen er something it was another provençal

The tension that is expressed between different forms of Provençal is one of authority and legitimacy. The elderly speakers' language is potentially more valuable on a Provençal linguistic market not because it is intrinsically better than theirs, or because it could index more authentically Provençal values, but because she is a native speaker, and can boast a state of monolingualism until the age of ten. This potentially threatening situation is therefore reframed into one of "difference but equality" between varieties. This enables both varieties to be equally authoritative, in the sense that the issue is not one of "proper Provençal vs. neo-Provençal”, but one of "old vs. new”, of natural change.

This last extract therefore shows that while the notion of "new language" language is available, it may be appropriated and negotiated in different ways that all encompass a dimension of authority and legitimacy on a given market, be it a unified linguistic market where old and new co-exist, or a more restricted linguistic market such as the classroom. Linguistic forms are used in particular ways that make use of categories of "old" and "new" in creative ways that allow the girls to position themselves in the world. It enables Carla to claim legitimacy through seniority, and Léa to state that she may be a bright student because she managed to learn Provençal in a short time. It permits a naturalised opposition between old and new that resolves the potential ideological tension between the monolingual native speaker and the second language learner by reducing both categories to naturally occurring variation. Finally, old and new can acquire different meanings on different markets according to what type of status participants wish to acquire; while in the school seniority may be an advantage, in other minority language contexts showing the goodwill of a new speaker may also bring symbolic benefits. In other words, one is always a new speaker for a 
particular purpose - be it to gain something, or to be prevented from achieving symbolic status.

\section{Conclusion}

In this article, I have sought to show that the very category of "new speakers" is one that can lead to contestation, appropriation by those who are indeed concerned (learners of minority languages), but which might also be used by individuals in language movements or in academia, for either descriptive or normative purposes. The "new speaker" category is not a neutral one, and its development, concomitant with the decline of many so-called minority languages and its appropriation by young, often middle class learners is likely to lead to a period of tensions on linguistic markets as authenticity, authority and legitimacy get redefined. Redefinition may occur on both political (who is considered a legitimate speaker of language $\mathrm{X}$ at large) and microsociological levels, as I have illustrated from the Provençal Calandreta example.

The new speaker concept generates two sets of problems, which I have tried to illustrate here. On the one hand, the term itself raises some questions, as it is already used in various circles to disqualify those who speak "new languages", i.e. languages that do not index traditional aspects of language use. On the other hand, people are learning minority languages throughout Europe and beyond, and this is changing linguistic scenes across the world. A wealth of languages are now available as post-vernacular languages in settings where they are no longer used by traditional speakers, while they may remain the preserve of first-language users in other areas. The confrontation between both types of settings, when it occurs, generates tensions in terms of legitimacy and authority. Both problems are of course connected, through their links with questions of legitimacy. Above all, what this suggests is that being a "new speaker" is very much about who one is in the world, either in one's own eyes, in those of other speakers to whom one looks up as a model, or in those of language activists, academics, teachers, all of which have various types of interests in establishing authority as to what the legitimate norm should be. In that respect, minority language markets are jealously guarded marketplaces, often small enough to be controlled relatively easily (especially as traditional speakers disappear), and the entry to which needs to be negotiated skilfully.

What the examples from language advocates, academics and pupils also highlight is the importance of the ideology of the native speaker and, above all, the monolingual speaker as the archlegitimate speaker. What particularly impressed the Calandreta pupils was the fact that Mrs R. had learnt French at the 
age of ten. This commanded respect, and led to the necessity to redefine their own practice. It is therefore interesting to note that as traditional speakers die out, minority languages do not necessarily become the spaces of freedom where artistic experiments can be conducted without judgement, as some activists claim in Provence. New linguistic regimes generate new conditions of legitimacy, and new questions about how social actors negotiate positions, identities and roles in a world where post-vernacular languages have largely become badges, for a wide array of purposes. What counts is more often that they are used at all and not what is said in them. In this respect, "new speakers" are not simply "learners" of a given language: they use language in a particular, symbolic way that relates to what it means to be "Provençal”, "Occitan", "Irish” or "Nahua”. They also raise further questions, in particular: why is this important, and to whom?

The discussion I provided in this article is, it should be emphasised, but a preliminary one, and issues of new speaker legitimacy in minority language contexts will have to be investigated further - in southern France and beyond. In particular, it is worth noting that traditional speakers may not view new speaker varieties as illegitimate on the surface; on the contrary, they may deem them ultra-legitimate as academic varieties, and may, as I have heard, call it "real Provençal" - unlike theirs, which they see as only patois. The result will be a very similar one however, and will only emphasise that what is at stake is not only language, but also and possibly above all the definition of social categories such as class, age or gender, and the respective positions of individuals in society.

\section{References}

Achard, Pierre. 1982. Preface. In Lluís Aracil, Lo bilingüisme coma mite [Bilingualism as Myth], 9-27. Magalàs: Institut d'Estudis Occitans.

Blanchet, Philippe. 1999. Parlons provençal. Paris: L'Harmattan.

Blanchet, Philippe. 2002. Langues, cultures et identités régionales en Provence : la métaphore de l'aïoli. Paris: L'Harmattan.

Bourdieu, Pierre. 1977. The economics of linguistic exchanges. Social Science Information 16(6). 645-668.

Bourdieu, Pierre. 1991. Language and symbolic power. Cambridge: Polity Press.

Costa, James. 2011. Du local au global : Essai de clarification idéologique préalable : Discours concurrents et revitalisation linguistique en Provence. In Francis Manzano (ed.), Unité et diversité de la linguistique, 233-255. Lyon: Publications du Centre d'Etudes Linguistiques.

Grinevald, Colette \& Michel Bert. 2011. Speakers and communities. In Peter K. Austin \& Julia Sallabank (eds.), The Cambridge handbook of endangered languages, 45-65. Cambridge: Cambridge University Press. 
Hincks, Rhisiart. 2000. Yr laith Lenyddol fel Bwch Dihangol yng Nghymru ac yn Llydaw - The literary language as a scapegoat in Wales and Brittany. Aberystwyth: Adran y Gymraeg, Prifysgol Cymru Aberystwyth.

Jaffe, Alexandra. 2009. Introduction: the sociolinguistics of stance. In Alexandra Jaffe (ed.), Stance: sociolinguistic perspectives, 3-28. Oxford \& New York: Oxford University Press. Jones, M. C. 1995. At what price language maintenance? Standardization in modern Breton. French Studies XLIX(3) 428-436.

Lafont, Robert. 1984. Pour retrousser la diglossie. Lengas 15. 5-36.

Lafont, Robert. 1997. Quarante ans de sociolinguistique à la périphérie. Paris: L'Harmattan.

Le Berre, Yves \& Jean Le Dû. 1999. Le qui pro quo des langues régionales : sauver la langue ou éduquer les enfants? In Christos Clairis, Denis Costaouec \& Jean-Baptiste Coyos (eds.), Langues et cultures régionales de France : Etat des lieux, enseignement, politiques, 71-83. Paris: L'Harmattan.

Legrand, Louis. 1993. Célestin Freinet (1896-1966). Prospects: The Quarterly Review of Comparative Education XXIII(1/2). 403-418.

Martel, Philippe. 2001. La France et l'occitan à l'époque contemporaine: histoire d'une étrange politique linguistique. In Henri Boyer \& Philippe Gardy (eds.), Dix siècles d'usages et d'images de l'occitan, 367-384. Paris: L'Harmattan.

O’Rourke, Bernadette \& Fernando Ramallo. 2011. The native-non-native dichotomy in minority language contexts: comparisons between Irish and Galician. Language Problems \& Language Planning 35(2). 139-159.

Shandler, Jeffrey. 2006. Adventures in Yiddishland: postvernacular language \& culture. Berkeley \& Los Angeles: University of California Press. 